\title{
Sexualidade E Riso \\ Uma leitura da crônica de Luís Fernando Veríssimo
}

\author{
Sexuality And Laugh
}

Fernando Moreno da Silva

UNESP-Universidade Estadual Paulista

Resumo: Partindo do pressuposto de que o riso é capaz de amenizar as tensões e derrubar tabus, o presente trabalho tem por objetivo, à luz da semiótica greimasiana, proceder a uma leitura da sexualidade no texto humorístico, analisando de que maneira a sexualidade é abordada e, a partir desta abordagem, como é construído o risível. Tomar-se-á, como objeto de análise, a crônica "Sissica", de Luís Fernando Veríssimo.

Palavras-chave: Semiótica; riso; leitura; sexualidade.

Abstract: Considering that laugh can split tension and break taboos, this paper has the aim to bring up a reading of sexuality from a humorous text, analyzed under the French semiotics theory. It will analyze how sexuality is brought to the text by the reader and, from this start, how laugh is built. As the object of analysis, it takes the chronicle "Sissica", by Luís Fernando Veríssimo.

Key-words: Semiotics, laugh, reading, sexuality. 


\section{O riso e suas expressões}

O estudo do riso se associa ao início da comédia na Grécia antiga, onde eram encenados feitos ritualísticos em louvor ao deus Dionísio. A comédia, no entanto, possuía uma importância secundária ante os espetáculos, já que era exposta nos intervalos das peças trágicas, com o intuito apenas de descontrair. De lá para cá, o riso ganhou muita importância, deixando de ser um mero instrumento de distração ou método paliativo.

Ainda que pudéssemos defini-lo, seria muito difícil tratá-lo exaustivamente. Podemos apontar, por questões didáticas, algumas manifestações do ridículo, ou seja, aquilo que provoca o riso. Na verdade, ridículo é um termo generalizante, um grande modo que se manifesta por diferentes expressões: cômico, humor, ironia, sátira, paródia, etc.

O cômico é a simples constatação do contraste, sem reflexão; é uma manifestação superficial. A partir do momento em que se estuda esse contraste, aprofundando-o numa reflexão, tem-se o humor. Pirandello (1996, p. 132) o define como o "sentimento do contrário". Citemos um exemplo para esclarecer: um homem de pijama, à noite, correndo debaixo de forte chuva, sem dúvida é hilariante. À primeira vista, é uma situação cômica, uma vez que contrasta com a normalidade. Se esse homem, porém, saiu dessa maneira, desesperado, à procura de ajuda, por causa do filho que passava mal em casa, causa-me grande compaixão. Aprofundando o contraste, tenho o humor, que se caracteriza como o riso discreto e complacente.

Uma outra manifestação do ridículo é a ironia, muito utilizada para exprimir o contrário do que se pensa. As palavras expressam o contrário da idéia que se pretende exprimir, mas se insere na mensagem um sinal que, de certa forma, previne o enunciatário das intenções do enunciador, ficando subentendido que tal recurso foi usado propositadamente. Dessa forma, o ironista pode muito bem apresentar como valorosa uma realidade que ele trata de desvalorizar. Ela assenta num jogo dialético: afirma para negar e nega para afirmar. Talvez uma das razões cruciais para o uso da ironia esteja na grande vantagem de se evitar a exposição direta dos ataques e críticas, ou de outras intenções que se queira atingir.

Por fim, podemos dizer que tanto o satirista quanto o parodista são conhecedores da cultura vigente, exigindo conhecimento de quem os lê. A sátira explora mais a ideologia, a ética, figurando uma arma crítica e agressiva, que está ligada à desmistificação dos costumes, da política, enfim, da ordem vigente. A paródia explora mais a estética e a linguagem, procurando imitar burlescamente o seu objeto. 


\section{A leitura em foco}

No processo da leitura há dois estágios ou, em outros termos, duas atividades no interior do ato: compreensão e interpretação. Inicialmente, o leitor atua na decodificação da superfície discursiva, englobando as organizações mórficas, sintáticas e semânticas. Exige-se na compreensão o reconhecimento extradiscursivo das regras de uso da língua natural. Num momento subseqüente, aprofundando a leitura, está a interpretação, que demanda um trabalho maior por parte do leitor, pois será necessário debruçar-se sobre as motivações ideológicas e inconscientes do texto, numa relação intertextual.

Todo enunciado produzido está imerso numa formação ideológica e numa formação discursiva, além de ser uma soma de outros discursos. Há uma complexidade em torno da idéia de sujeito. O "eu" é formado por uma ideologia, que, por seu turno, é formado por um feixe de fios ideológicos. Duas pessoas possuem valores em comum, mas também valores opostos. Por conseguinte, a competência de leitura está intimamente relacionada ao conhecimento enciclopédico do leitor; ele absorve um texto de acordo com sua vivência, aí incluídos " $n$ ” fatores: lingüísticos, culturais, religiosos, etc.

O enunciado tem como pressuposto o fato de ter sido proferido por alguém num tempo e num espaço. São as nuanças do processo enunciativo. O "eu" abarca duas instâncias: enunciador e narrador. No primeiro nível da enunciação, está o enunciador: é o "eu” pressuposto, equivalente ao autor implícito. É bom lembrar que autor implícito não é o mesmo que autor real. Ambos, por vezes, coincidem-se, mas não obrigatoriamente. A figura de carne e osso, pertencente ao mundo extralingüístico, pode fingir, criando, no discurso, a imagem de uma pessoa totalmente diferente de sua autêntica personalidade. Ele não pertence, portanto, ao texto. O enunciador, ao contrário, é uma imagem construída ao longo do texto, uma idealização do ser que produziu o discurso corrente. Traçando um paralelo com a Retórica clássica, cujo princípio preconiza, num ato de comunicação, o envolvimento de três componentes (orador, auditório e discurso), o enunciador seria, aproximando-o das tradições aristotélicas, o ethos do orador, a voz que ecoa numa construção discursiva.

Enquanto o enunciador é a instância pressuposta que produz o enunciado, o narrador, apresentando-se num segundo nível, é o "eu” projetado no interior do texto, fruto da criação do autor implícito. É uma delegação de voz levada a efeito pelo enunciador. 
Um último e terceiro nível surge quando o narrador delega voz aos actantes do enunciado. Nesse ensejo, aquele que fala se transforma no interlocutor. Na terminologia dos estudos literários, é a fala dos personagens. O sinal marcante para essa distinção é o uso do discurso direto, prestando-se a criar o efeito de sentido de realidade, pois parece que a própria personagem toma a palavra:

O discurso direto, em geral, cria um efeito de sentido de realidade, pois dá a impressão de que o narrador está apenas repetindo o que disse o interlocutor. Tanto esse fato é verdadeiro que, quando se narra em discurso direto, o que se pergunta ao narrador é se o interlocutor disse com aquelas palavras mesmo. (FIORIN, 1994, p. 79)

Sabe-se que, em todo processo de comunicação, a um "eu" corresponde sempre um "tu". Por isso, diante do enunciador está o enunciatário; do narrador, o narratário; do interlocutor, o interlocutário.

$\mathrm{Na}$ produção enunciativa, o enunciador invariavelmente considera a quem se destina seu discurso. Como numa comunicação epistolar, na qual se escreve sempre pensando naquele que irá ler a carta. Caso contrário, o discurso não alcança eficácia. Se, num desfile de modas, apresentamse modelos de roupas incrementados com peles de animais diante de uma platéia de ecologistas ou ambientalistas, certamente haverá protestos. Por ser levado em conta na construção do enunciado, afinal ele é a razão de existir do discurso, havendo diálogo entre emissor e receptor, o enunciatário faz parte do processo produtivo, constituindo-se um co-enunciador. Daí ser válida a asserção de que o sujeito da enunciação é composto por enunciador e enunciatário, já que este último influi visceralmente na forma e no conteúdo.

O enunciatário seria, nesse propósito, um destinatário implícito da mensagem, o leitor ideal. Muitos autores o têm denominado de formas variadas, mas todas conservando o mesmo significado: W. Iser emprega "leitor implícito"; J. Lintvelt, "leitor abstrato"; Umberto Eco, "leitor modelo". E mais uma vez é necessária a ressalva de que não se deve confundir o leitor virtual com o leitor empírico de carne e osso. Entre um ensaio filosófico e a narrativa do Chapeuzinho Vermelho é fácil construir a imagem dos seus respectivos leitores: para o primeiro, estariam os leitores críticos, ao passo que, ao segundo, o público infantil. Essa é, grosso modo, uma projeção dos leitores virtuais, mas nada impede que, na prática, um pesquisador vá ler um enredo infantil a fim de pesquisa ou vice-versa. 
Como destinatário do narrador está o narratário e, ao interlocutor, corresponde o interlocutário, igualmente um destinatário instalado, pelo narrador, dentro do discurso direto. Num diálogo, por exemplo, com travessão dentro de uma narrativa, interlocutor e interlocutário se invertem a cada momento em que um deles toma a palavra. Aquele que fala é o interlocutor, e aquele que ouve, o interlocutário; e vice-versa.

Após uma rápida discussão sobre os níveis enunciativos, cumpre destacar a produção discursiva. De saída, é necessário ressaltar que o texto não é somente um aglomerado de frases, mas uma unidade composta por uma macroestrutura, ou seja, um conteúdo semântico global. Para a consecução deste todo, há vários fatores que garantem a coerência textual. No nível das estruturas textuais, temos a coesão textual, que estabelece a relação interfrásica. Na estrutura narrativa, a narratividade tem o papel de costurar o discurso com seu fio narrativo. No nível da estrutura discursiva estão, de um lado, a argumentação "amarrando" o texto e, de outro, a coerência semântica alcançada por obra e graça das isotopias.

Para haver isotopia é preciso pelo menos duas unidades, pois o conceito de isotopia se refere à recorrência ou redundância de traços semânticos ao longo do discurso. Sua função é imprescindível para proporcionar ao discurso a sua coerência. Como se sabe, um texto pode desencadear " $n$ " leituras. No entanto, a leitura total também é ilusória, sendo necessário delimitála. É justamente a isotopia, segundo Greimas (1975, p. 22), "que permite superar os obstáculos opostos à leitura pelo caráter polissêmico do texto manifestado".

Ela irá se realizar em dois níveis de construção de sentido. No primeiro nível de leitura, temos a presença de figuras, que são palavras concretas que nos remetem a imagens do mundo real. É no nível figurativo, referindo-se a espaço, tempo e personagens, que se cria o efeito de sentido de realidade: noite, favela, revólver, tiros, pessoas assustadas, sirenes... Com tais palavras, presume-se que talvez tenha ocorrido um crime. Partindo para esta primeira operação de abstração, ou seja, formulando valores, entramos no segundo nível de leitura, chamado temático. O tema ou nível temático (crime) é uma abstração, podendo ser recoberto por figuras (noite, favela, revólver, etc.).

É exatamente a reiteração dos temas e figuras ao longo do texto, construída pela recorrência de traços semânticos, ou seja, a isotopia, que garantirá a coerência do discurso. Quando as mesmas figuras permitem associar temas diferentes, possibilitando leituras distintas, surgem os conectores de isotopia. Exemplo: Em um diálogo, se alguém diz "Ricardo Briguento", o 
termo "briguento" pode receber duas interpretações: ser um sobrenome ou um adjetivo depreciativo.

Para demonstrar de forma mais clara que, apesar de um texto possibilitar uma infinidade de leituras, há limites a essa liberdade, inscritos no próprio texto, amparando a sua interpretação, toma-se a crônica "Sissica” (em anexo), de Luís Fernando Veríssimo.

\section{Análise da crônica}

A história se passa numa sala de espera do aeroporto. Num entremeio de total silêncio, o telefone celular de um homem toca. Naquele instante, ele dá início a uma conversa muito íntima com uma mulher do outro lado da linha. Supõe-se que sua interlocutora é sua mulher, namorada ou amante, em virtude das expressões típicas empregadas por um casal. Esse diálogo, quebrando o silêncio imperante até então, com termos que sugerem obscenidade, proferidos publicamente, de viva voz, causam constrangimento geral entre os integrantes daquela sala, com situações bizarras e dignas de riso. O desfecho da narrativa, após uma celeuma e conseqüente debandada, termina com uma revelação surpreendente, pondo fim à tensão construída ao longo do texto: a pessoa do outro lado da linha, com a qual o homem conversava, era sua própria filha.

A crônica baseia-se num paralelo entre o discurso direto (conversa ao telefone pelo interlocutor, criando o efeito de sentido da realidade) e o discurso indireto (assumido pelo narrador que descreve as situações numa sala de espera do aeroporto). Antes da instauração desse paralelo, há um estado conjuntivo de relaxamento. O clima na sala de espera era pacato até o celular tocar.

Querida: indica que do outro lado da linha há uma mulher

Devo chegar: a mulher está esperando

Meia-noite: o horário do encontro, à noite

Esperar acordada?: tudo preparado para o encontro

$A h, e ́$ ?: confirmação de que irá esperar

Aquele curtinho: roupa sensual

Ai meu Deus: expressão idiomática, demonstrando excitação da libido

E o que você vai me dar?: provocação

Estou levando: talvez um presente

Na maleta: indica que está bem guardado

Pilha nova: revela que talvez seja um vibrador ou um outro objeto de sex shop 
CASA Vol. 3.n.1, agosto de 2005

Te prepara: aviso de vigor e apetite sexual

Sissica: hipocorístico indicando intimidade

Cê vai fazer o quê?: talvez uma fantasia para sair da rotina

Detendo-nos nas figuras do diálogo, é possível encontrar basicamente a isotopia da sexualidade. $\mathrm{O}$ enunciador lança mão da sexualidade para dois fins. $\mathrm{O}$ primeiro é provocar o efeito de sentido do riso. Falamos num efeito porque o riso não está presente no discurso, mas sim no enunciatário. Mas como podemos dizer, então, que há esse efeito? Para poder explicar esse mecanismo, o reconhecimento intradiscursivo não dá conta, sendo necessário recorrer ao interpretante ideológico, numa relação heterodiscursiva.

A inserção do efeito risível é, acima de tudo, uma prática social. A conversa reservada entre duas pessoas é algo totalmente normal, mas a consciência coletiva está ciente, no entanto, de que há o local apropriado para exercê-la. Quando essa intimidade é exposta ao público, há uma certa inconveniência. Desse choque entre íntimo e público, as reações são das mais variadas. Inicia-se um estado não-conjuntivo de intensão. Essa quebra da normalidade, provocando o contraste, é suscetível de engendrar o efeito de sentido do riso no enunciatário.

A partir daí, as cenas cômicas ocasionadas pelo diálogo passam por três etapas. Num primeiro momento, irá provocar curiosidade: "Saco, ser obrigado a ouvir a conversa dos outros daquele jeito. E não poder ouvir o que estavam dizendo do outro lado”. Aliás, o narrador revela tal curiosidade por meio de uma ironia: "As outras vinte e nove pessoas continuavam fazendo o que se faz numa sala [...] E fingindo que não ouviam a conversa". Depois, quando a conversa envolve intimidade ("Você vai me esperar acordada?”; "Qual, aquele curtinho?"), desperta inquietação entre as pessoas, em virtude do pudor. O incômodo se deve também à presença das duas freiras. Todos ficam envergonhados diante de uma conversa tão "profana":

Mexe-mexe nas cadeiras

Arrastar de pés

Um casal que [ ] ficara em silêncio [ ], agora falando mais alto

Alguns olharam para as duas freiras

O homem mais velho empinou a cabeça num espasmo

Duas outras pessoas levantaram-se rapidamente 
As expressões utilizadas pelo interlocutor também são construções risíveis. Ao utilizar "furúnculo", "supurando", "roxo meio esverdeado" e "bem na dobra", fazem-nos rir, pois o incômodo que antes era provocado pelo pudor agora se transforma em repugnância:

\author{
Uma mulher soltou uma espécie de grito e depois tentou disfarçar \\ O homem mais velho se levantou [...] Afastou-se quase correndo \\ Mais pessoas saíram de perto [...] \\ O casal aumentou o volume da sua conversa \\ Pessoas que nunca tinham se visto antes agora puxavam conversa \\ Várias pessoas estavam agora de pé [...] Caminhavam de um lado para o outro \\ Houve uma debandada
}

Cada uma das etapas descreve uma gradação contínua da tensão. As reações das pessoas denotam um estado totalmente disjuntivo. Além de cômico, esse percurso figurativo reveste o tema da sociabilidade. Nos dois momentos de dispersão, primeiro a inquietação por causa da conversa “obscena”, depois, pelo nojo, procura-se demonstrar o quanto é difícil a convivência num meio em que há pessoas que não respeitam os outros indivíduos.

Bem, até o momento, discorremos sobre a preocupação geral do enunciador, que foi construir, ao longo da crônica, uma sátira sobre a insociabilidade e desrespeito daquele que vive em grupo. Atendo-se, a partir de agora, a uma crítica específica do enunciador, analisaremos o percurso figurativo da religião. Eis o segundo motivo pelo qual o enunciador lança mão da isotopia da sexualidade, justamente para enfocar as religiosas.

A figura das freiras recebe uma atenção especial do narrador. A todo o momento, ele recorre a elas para representar a tensão provocada pela fala ao telefone. Até então, as atitudes das freiras eram de perplexidade, cômicas:

Mantinham os olhos baixos e não se mexiam.

As freiras continuavam de olhos postos no chão.

Mas o crescendo da tensividade do ambiente acaba por se interiorizar no íntimo das religiosas. A partir daí, o espanto dá lugar a outros pensamentos. Nesse momento, os dois percursos figurativos marcantes na crônica, sexualidade e religião, entram em oposição, perpassando vários temas, como a castidade e o pudor. Ao ouvirem aquela conversa íntima entre 
um homem e uma mulher, as duas freiras passam por um processo de tentação, uma briga entre os desejos da carne e a santidade?

\footnotetext{
Uma das freiras olhou para o alto com um sorriso triste enquanto a outra se encurvou para olhar o chão mais de perto.[...]

As duas sacudiram a cabeça. Ficariam firmes, o Senhor lhes daria força [...]

Só as duas freiras continuaram sentadas, com os olhos fechados e uma expressão de martírio, entre doce e dolorida, no rosto.[...]
}

Essa situação fez com que elas permanecessem num estado limítrofe entre o sagrado e o profano: sofrimento e resignação, dor e doçura.

O quadrado semiótico pode muito bem representar essa posição intermediária, que designaremos "não-sagrado". De um estado sagrado, caracterizado pelo espanto das duas, elas se aproximam, em virtude das imaginações, de um estado profano, sem inteiramente assumi-lo:

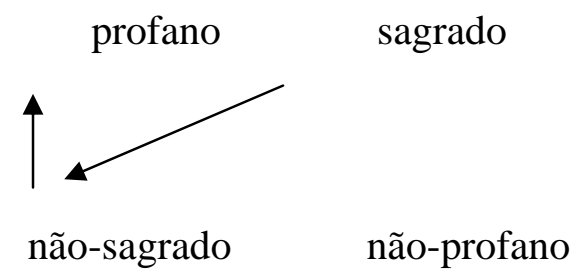

Pontuando apenas o comportamento das freiras, estamos diante do humorismo. Não há dúvidas de que o emprego do humor tem uma função desmistificadora, figurativizando o quanto é ilusória e penosa a realidade vivida por aquele que segue o celibato. Ampliando essa visão, focando agora no contexto geral do texto, a angústia retratada pelo humor se transforma numa sátira, revelando a instabilidade e a fraqueza do ser humano. Com isso, há uma ridicularização da rigidez com que a religião estabelece seus preceitos, como a proibição do sexo à classe eclesiástica.

Entremeado ao processo de tentação, há o percurso temático do assédio sexual, numa ironia muito bem elaborada pelo cavalheirismo:

I.

Um homem, fora de si, veio perguntar se as duas não gostariam de ir ao banheiro. Ele as acompanharia $[\ldots]$ 
O fim da crônica é marcado pela quebra de expectativa. Para sustentar essa expectativa, em nenhum momento o narrador deu a palavra à interlocutora do outro lado da linha. Ao longo da conversa do homem ao celular, com as expressões por ele utilizadas, presumia-se apenas uma conversa íntima de um casal. O mistério foi mantido até o final. Criou-se, portanto, uma imagem de sexo. Mas o desfecho desencadeia uma frustração ao ser revelado que a conversa era a relação inocente entre pai e filha. No tocante ao ambiente da sala de espera, com a revelação, há um retorno ao estado de relaxamento inicial, experimentado somente pelas duas freiras, afinal, todos já haviam se retirado da sala de espera.

A sexualidade, que antes se presumia, nada mais era do que a espera ansiosa de uma filha por seu pai. Portanto, as figuras que formavam a isotopia da sexualidade se transformam em conectores de isotopia, pois ligavam a isotopia da sexualidade à da relação paternal.

\section{Conclusão}

Com a análise, a primeira constatação a que podemos chegar é que o riso é um efeito de sentido, estando presente no enunciatário e não necessariamente no texto. E as razões pelas quais o enunciador utiliza-se dele podem ser inúmeras. No caso específico do texto de Veríssimo, como é sabido, ele figura entre os escritores mais lidos do país. Por isso, podemos pressupor que todas as suas crônicas têm um enunciatário previamente estabelecido, ou seja, aquele leitor que busca no seu texto a leitura de passatempo.

Não levando em consideração a questão extratextual ou mercadológica, avaliando tãosomente a produção discursiva, como foi o intento dessa análise, podemos perceber que o riso é um recurso usado para tratar de assuntos polêmicos e, por vezes, proibidos. Ele é um meio para se chegar a um fim. Ao lado da ironia, sátira e outros recursos risíveis, o enunciador toca de forma aparentemente despretensiosa em temas delicados, que talvez implicassem a ira, caso fossem abordados com seriedade.

Para ilustrar o funcionamento do riso, podemos empregar uma metáfora. O xingamento de uma criança dirigido a um adulto seria encarado com naturalidade, interpretado como uma infantilidade. Porém essas mesmas palavras desonrosas, proferidas por um adulto, seriam encaradas como uma ofensa inadmissível. O riso, portanto, é o moleque travesso que tem a permissão de falar livremente sem ser repreendido, caindo nas graças. 


\section{Anexo}

\section{SISSICA}

Não sei se fecha com a estatística geral, mas, naquela sala de espera do aeroporto, entre trinta pessoas, uma tinha telefone celular. E ele tocou.

— Alô? Eu. Oi, querida.

As outras vinte e nove pessoas continuaram fazendo o que se faz numa sala de espera de aeroporto quando o avião atrasa. Lendo, tentando dormir, olhando fixo para nada. E fingindo que não ouviam a conversa.

— Não, ainda estou no aeroporto. O avião atrasou. Sei lá. Devo chegar pela meia-noite.

Um homem mais velho sacudiu a cabeça com leve irritação. Saco, ser obrigado a ouvir a conversa dos outros daquele jeito. E não poder ouvir o que estavam dizendo do outro lado.

— Você vai me esperar acordada? Ah, é? Quero só ver. Qual, aquele curtinho? Ai meu Deus. Já estou vendo. E o que é que você vai me dar? Hein?

Houve uma certa inquietação em torno do homem que falava. Um certo mexe-mexe nas cadeiras e arrastar de pés. Um casal que já conversara muito e ficara em silêncio retomou a conversa, animadamente, agora falando mais alto. Alguns olharam para as duas freiras que, a poucos metros do homem do celular, mantinham os olhos baixos e não se mexiam.

— O quê? Estou levando, sim. Está aqui na maleta. E com pilha nova. É. Te prepara, Sissica.

Ao som de "Sissica" o homem mais velho empinou a cabeça num espasmo involuntário e duas outras pessoas levantaram-se rapidamente e dirigiram-se para o bar, para a livraria, para qualquer ponto longe daquele celular e do seu dono. As freiras continuavam de olhos postos no chão.

— Cê vai fazer o quê? Ah, é? Tá bom. Só acho que hoje eu não vou poder, não. Tou com um furúnculo.

Uma mulher soltou uma espécie de grito e depois tentou disfarçar com tosse. O homem mais velho também se levantou, olhou para o relógio, exclamou "Não é possível" e foi procurar alguém da companhia para reclamar do atraso. Afastou-se quase correndo.

— Sei lá. Apareceu hoje. E acho que está supurando. Tá um roxo meio esverdeado.

Mais pessoas saíram de perto, procurando o que fazer. O casal aumentou o volume da sua conversa, tentando falar mais alto do que o homem. Outros também começaram a falar. Pessoas 
que nunca tinham se visto antes agora puxavam conversa uma com a outra e todas falavam ao mesmo tempo. Mas o homem do celular falava mais alto.

- Onde? É, lá mesmo. Bem na dobra.

Uma das freiras olhou para o alto com um sorriso triste enquanto a outra se encurvou para olhar o chão mais de perto. Um homem, fora de si, veio perguntar se as duas não gostariam de ir ao banheiro. Ele as acompanharia. As duas sacudiram a cabeça. Ficariam firmes, o Senhor lhes daria força.

— Como é que eu sei que ta roxo? Eu olhei, né Sissica. Com um espelho. Rá, cê pensou o quê?

Várias pessoas estavam agora de pé, tomadas de uma súbita revolta com aquela demora no embarque. Caminhavam de um lado para o outro. Por que o avião não saía?

- Cê pensa que eu pedi pra camareira olhar, é? Dá uma olhadinha aqui no meu furúnculo, minha filha, pra ver que cor é. É só levantar o...

Houve uma debandada. Algumas pessoas se precipitaram para o balcão de informações e começaram a bater com os punhos no balcão, exigindo embarque imediato ou explicações. Outras se dispersaram pelo aeroporto, em pânico. Só as duas freiras continuaram sentadas, com os olhos fechados e uma expressão de martírio, entre doce e dolorida, no rosto. Finalmente o homem despediu-se da Sissica, guardou o celular no bolso e disse para as freiras:

- Minha filhinha. Estou levando um joguinho eletrônico para ela e...

Então o homem se deu conta de que a sala de espera estava vazia e perguntou:

— Ué, já chamaram?

\section{REFERÊNCIAS BIBLIOGRÁFICAS}

BARROS, Diana Luz Pessoa de. Teoria do discurso: Fundamentos semióticos. São Paulo: Atual, 1988.

BERTRAND, Denis. Caminhos da semiótica literária. Bauru: EDUSC, 2003.

CULLER, Jonathan. Greimas y la semántica estructural. In: La poética estructuralista:

El estructuralismo, la lingüística y el estudio de la literatura. Barcelona: Editorial Anagrama, 1975. Cap. 4, p. 113-140.

FIORIN, José Luiz. As astúcias da enunciação: as categorias de pessoa, espaço e tempo. Tese de livre-docência da Universidade de São Paulo (Faculdade de filosofia, letras e ciências humanas). São Paulo, 1994. 
CASA Vol. 3.n.1, agosto de 2005

GREIMAS, Algirdas Julien (org). Ensaios de semiótica poética. Trad. de Heloysa de Lima Dantas. São Paulo, Cultrix/EDUSP, 1975.

Semântica estrutural. Pesquisa de Método. Tradução de Haquira Osakabe e Izidoro Blikstein. São Paulo: Cultrix/EDUSP, 1976.

MINOIS, Georges. História do riso e do escárnio. Trad. de Maria Elena O. Ortiz Assumpção. São Paulo: Editora UNESP, 2003

PIRANDELlO, L. O humorismo. Trad. de Dion Davi Macedo. São Paulo: Experimento, 1996. 